\title{
Choice as Regulatory Reform: The Case of Japanese Corporate Governance
}

\author{
Ronald J. Gilson* and Curtis J. Milhaupt**
}

\begin{abstract}
$\underline{\text { Abstract }}$
In this paper, we examine a unique recent approach to corporate governance reform in Japan. The reform permits firms to switch from "Japanese" to "U.S" board structure, featuring independent committees of the board for audit, compensation, and nomination. We examine the first year of adoptions (the 2003 annual shareholders meeting season) in this natural experiment, frame hypotheses concerning why Japanese firms might make the switch, and conduct an event study to assess the hypotheses in light of the market's reaction to firm announcements of the decision to switch. We conclude with an intellectual roadmap for future reform of Japanese corporate governance, highlighting a potential shortcoming in the new board option.
\end{abstract}

Detailed analysis of the adoptions reveals several surprising findings. First, cross-listing on a U.S. exchange is not highly predictive of the switch to a U.S. board committee structure. Second, firms which are part of a corporate group - including most prominently the Hitachi group - comprise about half the total adoptions. Adopting firms are also about evenly divided between globally active firms with a high percentage of foreign shareholders, and those with low international profiles.

We suggest four hypotheses to explain why a Japanese firm might switch to a U.S. board structure: (1) the belief that U.S. corporate governance structures are superior to Japanese structures, so that the adoption serves a signaling and bonding function; (2) endogeneity, as firms for whom the committee structure is efficient (costly) adopt (resist) the new governance option; (3) strengthening of parent company control over group firms (made possible by the Japanese Commercial Code's very broad definition of outside director, which includes directors affiliated with parent firms and major shareholders); and (4) indeterminacy, as political economy tensions about the appropriateness of the reform apparent in the enactment process are replicated in the adoption/non-adoption process. Our event study results show no pattern of significant market price movement on announcement either for the entire sample or for subsamples (though several firms individually experienced significant market price movements). Thus, the results are consistent with both the weakness of the signal sent by switching, and the limited impact of the amendments.

We conclude with a cautionary note, suggesting that future development of Japanese corporate law may be compromised by use of the new committee structure in tandem with the Code's broad definition of outside director. The combination may create a powerful new technology for managerial entrenchment and what we call "stakeholder tunneling"- the diversion of firm assets and revenues away from shareholders and toward employees, banks and other constituencies.

\footnotetext{
* Charles J. Meyers Professor of Law \& Business, Stanford Law School and Marc \& Eva Stern Professor of Law \& Business, Columbia Law School. Email: rgilson@law.columbia.edu

${ }^{* *}$ Fuyo Professor and Director, Center for Japanese Legal Studies, Columbia Law School. Email: milhaupt@law.columbia.edu

Helpful comments on an earlier draft were provided by participants at the Vanderbilt Law and Business Workshop and the Mitsui USA Symposium. Keiji Hatano, Columbia LLM 2004, provided excellent research assistance.
} 


\section{Choice as Regulatory Reform: The Case of Japanese Corporate Governance}

\section{Ronald J. Gilson* and Curtis J. Milhaupt ${ }^{* *}$}

Corporate governance reform is everywhere these days, and it has a common focus. In many markets, including the United States, governments and stock exchanges have entered the board room, enacting mandatory rules on board composition, director independence, and other aspects of firm organization previously left to private ordering between shareholders and managers. ${ }^{1}$ As we will explore in this Article, extensive corporate governance reforms on board structure and composition are taking place in Japan as well, but the reforms have taken a highly distinctive turn.

Japanese corporate governance in the postwar period has been both insular and conservative. It is insular in that Japanese corporate governance has a unique structure what economist Masahiko Aoki calls J-Form - that is said to reflect the special characteristics of Japan, whether cultural or industrial. ${ }^{2}$ It is conservative in that in the familiar account, Japanese corporate governance largely walls off company management from external pressure, whether from the market or from shareholders. While a main

\footnotetext{
${ }^{*}$ Charles J. Meyers Professor of Law \& Business, Stanford Law School and Marc \& Eva Stern Professor of Law \& Business, Columbia Law School. Email: rgilson@law.columbia.edu

${ }^{* *}$ Fuyo Professor and Director, Center for Japanese Legal Studies, Columbia Law School. Email: milhaupt@law.columbia.edu

Helpful comments on an earlier draft were provided by participants at the Vanderbilt Law and Business Workshop and the Mitsui USA Symposium. Keiji Hatano, Columbia LLM 2004, provided excellent research assistance.

${ }^{1}$ This is the essence of the Sarbanes-Oxley reforms and New York Stock Exchange Listing standards enacted in the wake of the Enron and WorldCom scandals. In Asia, the 1997-98 financial crisis had a similar effect: Korea and Taiwan enacted mandatory board reforms, featuring independent directors, for publicly traded firms in response to problems exposed in that episode.

${ }^{2}$ For the original formulation, see Masahiko Aoki, Toward an Economic Model of the Japanese Firm, $28 \mathrm{~J}$. Econ. Lit. 1 (1990).
} 
bank may intervene in circumstances of distress, intervention comes from within rather than from without, and later in the process than would be the case with U.S and U.K. and, increasingly, European corporate governance.

In response to 13 years of poor economic performance and, at least until the finde-siecle U.S. corporate governance scandals, the view that the Anglo-American system may be the evolutionary pinnacle of corporate governance structures, ${ }^{3}$ Japan in 2002 dramatically reformed its corporate governance system. ${ }^{4}$ It did so, however, in a characteristically unusual fashion. Rather than adopting a blanket reform of its corporate law that applied to all corporations, as has been the strategy, for example, in the transition economies arising out of the break up of the Soviet Union or Korea following the Asian financial crisis, ${ }^{5}$ Japan elected an enabling strategy of reform. Beginning in 2003, Japanese companies have the option to choose features of a U.S./U.K. style governance structure, centered on a board of directors and committee structure, or to adhere to their traditional, statutory auditor structure. ${ }^{6}$

An enabling strategy has the attraction of being ecumenical. Generalizing the fact, stressed in the Japanese context by Aoki, that governance structure and industrial organization are complementary, an approach that allows Japanese corporations a choice between traditional and U.S/U.K style governance permits corporations to elect a

\footnotetext{
${ }^{3}$ This sentiment emerged out of the performance of the U.S. economy in the 1990s and crystallized in the response of international agencies to the 1997-98 Asian financial crisis. See. e.g., Ronald J. Gilson, Globalization of Corporate Governance: Convergence of Form or Function, 49 Am. J. Comp. L. 329, 331 (2001). However, even before the U.S. scandals, the idea that U.S. corporate governance was a model for Asia was a highly controversial idea, embraced by only certain segments of the population.

${ }^{4}$ As discussed in part I, there had been interstitial reform of some importance throughout the 1990s.

${ }^{5}$ See Bernard S. Black, Hasung Jang \& Woochan Kim, Does Corporate Governance Predict Firms' Market Value? Evidence from Korea, unpublished paper, available at http://papers.ssrn.com/abstract=311275; Bernard Black, Does Corporate Governance Matter? A Crude Test Using Russian Data, 149 U Pa. L. Rev. 2131 (2001).

${ }^{6}$ See TAN 28-34 infra.
} 
governance structure best suited to their particular circumstance. We now have data on the choices made by Japanese corporations in the first cycle since the reform was adopted. In total, as of March 31, 2004, seventy one firms chose to adopt the U.S./U.K. governance structure, including forty five out of about 3000 publicly traded Japanese companies.

While the results of the first choice cycle provide only a preliminary indication of the reform's effects, especially in country that is slow to change but capable of enormous change once engaged, ${ }^{7}$ in this Article we make a first effort at assessing the patterns, if any, reflected in the initial decisions made by large Japanese corporations. A number of strategies may be reflected by a corporation's choice of governance structure. In general, the choice may be part of a signaling strategy, allowing the corporation to credibly inform outsiders of its future plans. The globalization of the capital market and the growing importance of institutional investors with announced preference for "westernstyle" corporate governance may lead companies expecting to access the global capital market to select that market's preferred governance structure.

Alternatively, companies may choose a governance structure based on their particular form of industrial organization. Aoki has long argued that the characteristics of Japanese corporate governance are linked to the particular strengths of Japanese production - large investments in firm specific human capital that allowed extremely rapid response under conditions of linear change in the product markets, as exemplified

\footnotetext{
${ }^{7}$ The two most prominent examples are the Meiji reforms of the late $19^{\text {th }}$ Century and the post-World War II period. On the Japanese reaction to the post-war occupation, see John W. Dower, Embracing Defeat (1999). The late $20^{\text {th }}$ century economic and legal reforms in Japan may not compare in scale or urgency to these historical examples, but it seems quite plausible that the current period may one day be viewed as a significant moment in Japan's institutional development.
} 
by Japanese manufacturing techniques. ${ }^{8}$ From this perspective, a company's substantive activity will drive the choice of governance structure. Companies whose production is characterized by firm specific human capital and linear change will retain the traditional Japanese governance structure. In contrast, companies for whom the ability to respond quickly to non-linear change in the economic environment is critical will elect a westernstyle governance structure. ${ }^{9}$

An additional feature of traditional Japanese governance may also influence the choice of governance structure. Corporations that are part of a keiretsu corporate group centered around a main bank may confront higher barriers to change that reduce the attractiveness of the choice offered by the reform. Members of a keiretsu get something from keiretsu structure that is easy to accomplish under the traditional corporate governance structure but may be more difficult to achieve through alliances under U.S./U.K. governance. Moreover, the keiretsu structure may imply a different pattern of decision-making; the process of collective choice among members of the group may result in initial delay in selecting reform followed by a cascade of elections. Election cascades may also occur as result of herd behavior, particularly where a group or industry leader's adoption induces the fear of being left behind in related or rival firms and where mimicking the signal proves too easy.

Finally, there is simply Newton's First Law of Motion. Objects (and organizations, especially conservative organizations), tend to remain at rest unless compelled to change; the forces of change must be pressing before the internal politics

\footnotetext{
${ }^{8}$ See Aoki, supra note 2; Masahiko Aoki, Information, Corporate Governance, and Institutional Diversity: Competitiveness in Japan, the United States, and the Transitional Economies (Stacey Jehlik trans., 2000).

9 See, e.g., Ronald J. Gilson, The Political Ecology of Takeovers: Thoughts on Harmonizing the European Corporate Governance Environment, 61 Fordham L. Rev. 161 (1992); Ronald J. Gilson, Corporate Governance and Economic Efficiency: When Do Institutions Matter?, 74 Wash U. L.Q. 327 (1996).
} 
supporting the status quo give way to reformers. ${ }^{10}$ The political-economy version of Newton's insight suggests that the 2002 reform may initially meet with substantial resistance.

The 2002 reform presents a unique natural experiment in the attractiveness of U.S.-style corporate governance structures abroad. At this early stage, analysis of the experience with the Japanese effort at corporate governance reform through choice can be no more than suggestive. However, it should be helpful even at this stage to use this experience to frame the areas of inquiry that will be central to assessing the results as the passage of time expands the sample to be studied. Our principal aim, beyond reporting the preliminary evidence on this natural experiment, is to sketch an intellectual roadmap for thinking about the trajectory of corporate governance reform in Japan.

Our effort proceeds as follows. Part I briefly outlines the main features of corporate governance reform that culminated in the enabling approach, highlighting the dynamics that set this change in motion. Part II describes the effort at regulatory reform through choice. Part III sets out the data—the seventy one corporations that have elected US/UK corporate governance and several salient characteristics of the adopting firms. Part IV then assesses what can be learned about the strategies of choice from the early experience with the reform, and reports the results of an event study undertaken to assess the importance of those strategies in the first round of adoptions. Part V provides a preliminary appraisal of Japan's use of choice as a tool of corporate governance reform.

\footnotetext{
${ }^{10}$ Mancur Olson, The Rise and Decline of Nations: Economic Growth, Stagflation, and Economic Rigidities (1982).
} 


\section{A Decade of Corporate Governance Reform in Japan}

The 2002 amendment to the Commercial Code permitting choice in board structure caps a decade of corporate governance reform in Japan. Since a basic understanding of the content and dynamics of these reforms is necessary to a complete understanding of the 2002 reform and its early aftermath, we begin with a brief and somewhat stylized tour through ten years of corporate law reform.

The first point to note is the sheer volume of reform that has taken place. The past ten years witnessed the most extensive and rapid amendments to Japanese corporate law (found principally in the Commercial Code) since its enactment a century ago. ${ }^{11} \mathrm{We}$ list the major reforms chronologically in Table 1 . As can be seen from the Table, the Commercial Code has been amended virtually every year, with multiple amendments in some years.

\begin{tabular}{|l|l|}
\hline \multicolumn{2}{|c|}{ Table 1: Major Commercial Code Amendments 1993-2002 } \\
\hline 1993 & Fixing fee of 8200 yen for shareholder derivative suits \\
\cline { 2 - 3 } & Introducing a board of statutory auditors [kansayakukai] \\
\cline { 2 - 3 } & Reducing shareholding threshold to demand inspection of records \\
\hline 1994 & Deregulating limitations on repurchase of shares (1) \\
\hline 1997 & Introducing stock option system (Deregulating limitations on repurchase of shares (2)) \\
\cline { 2 - 3 } & Simplifying merger procedures \\
\hline 1998 & Deregulating limitations on repurchase of shares (3) \\
\hline 1999 & Creating share exchange system \\
\hline
\end{tabular}

${ }^{11}$ See Curtis J. Milhaupt, A Lost Decade for Corporate Law Reform in Japan?: What's Changed, What Hasn't, and Why (Columbia Law School Law, Center for Law and Economic Studies Working Paper (2003); Hideki Kanda, Reforms in Corporate Law and Financial Regulation in Japan. Unpublished manuscript (2000). 


\begin{tabular}{|c|c|}
\hline 2000 & Creating company spin off system \\
\hline \multirow[t]{4}{*}{2001} & Lifting ban on treasury stock \\
\hline & Creating new stock acquisition right [shin kabu yoyaku ken] system \\
\hline & Expanding the authority of statutory auditors \\
\hline & Authorizing limitations on managers' liability \\
\hline 2002 & $\begin{array}{l}\text { Creating an option to form committees of the board of directors in lieu of the statutory } \\
\text { auditor system }\end{array}$ \\
\hline
\end{tabular}

In broad terms, most of these amendments can be characterized as advancing one of two goals: expanding the choice set of Japanese managers by enhancing organizational flexibility and increasing corporate finance options, or improving the monitoring capabilities of the board and other corporate organs. The flexibility enhancing amendments, for example, eliminated the prohibition on holding companies, streamlined merger and divestiture procedures, and facilitated the issuance of stock options and other equity or equity-like instruments. The monitoring enhancing amendments include procedural changes to the shareholder derivative suit mechanism and structural changes to the statutory auditor system and the board of directors. As we will see below, the 2002 enabling approach seeks to advance the goals of increasing both flexibility and monitoring.

While we leave a thorough evaluation of these interstitial corporate law reforms to other work, ${ }^{12}$ a brief discussion of several points will help readers understand the import of the 2002 reform. Reflecting German influence on Japanese corporate law, a basic component of the traditional corporate governance structure is the statutory auditor

\footnotetext{
${ }^{12}$ See Milhaupt, supra note 11.
} 
[kansayaku]. The Japanese statutory auditor, however, is weaker than its German counterpart, the supervisory board. The Japanese statutory auditor lacks the power to appoint or remove directors, and does not necessarily represent shareholder or employee interests, since auditors are nominated by the board. The sole functions of the statutory auditor are to monitor the board's compliance with law and to review the financial statements. Dissatisfaction with the auditor system is longstanding and widely, though not universally, shared. Over the past decade, several attempts were made to strengthen the auditor system. Amendments in 1993 extended the auditor's term of office and mandated that large companies have at least three auditors, rather than a minimum of one, and that they function as a board of audit. One member of the board of audit must be an outside auditor. ${ }^{13}$ In 2001, amendments sought to further strengthen the auditor regime by extending the term of office and responsibilities of auditors, while increasing the required number and qualifications of outside auditors. ${ }^{14}$ Effective in 2005, at least half of the board of audit must be comprised of outside auditors.

Legally, the Japanese board of directors, like its U.S. counterpart, is charged with monitoring corporate activity and vested with authority to make important managerial decisions. ${ }^{15}$ In fact, however, Japanese boards have not traditionally emphasized their monitoring role. Widely shared beliefs about board membership created boards ill-suited to perform this role. Throughout the postwar period, Japanese boards have been comprised almost exclusively of senior managers who have served the corporation

\footnotetext{
${ }^{13}$ Law for Special Exceptions to Commercial Code Concerning Audit, Etc. (Special Exception Law), Arts. 18(1), 18-2(1).

${ }^{14}$ Special Exception Law, Art. 18(1) (at least half the audit board must be comprised of outside auditors); Commercial Code Art. 260-3(1) (requiring auditors to attend meetings of the board); Art. 273(1) (four year term).

${ }^{15}$ Commercial Code, Art. 260.
} 
throughout their careers - typically one director from each of the firm's major divisions. As such, board members were viewed as representing employees, or perhaps the division from which they were appointed. Since board membership was viewed as a status position--the ultimate reward for loyal service to the firm--boards tended to be very large and virtually devoid of independent members. Moreover, it was commonly understood that a few senior directors, acting informally as a management committee, or a single "representative" director, would have the ultimate decisionmaking authority, rather than the board as a whole. These discrepancies between the formal role contemplated for the board in the corporate law and the role actually played in practice led a blue ribbon corporate governance panel to conclude that " $[\mathrm{i}] \mathrm{t}$ is questionable whether the Japanese board of directors actually complies with the Commercial Code's stipulation that it function[ ] as the body which decides on corporate will and exercises corporate oversight." 16

In an effort to enhance the effectiveness of the board as a monitoring device, Japanese firms began to experiment informally with several reforms beginning in the late 1990s. Sony, for example, reduced the size of its board and began to include outside directors on the board. Survey data show an increase from 28.6 percent to 46.2 percent in firms displaying particular interest in reducing the number of directors between 1998 and $2000 .{ }^{17}$ Of the firms reducing the size of their boards, 80 percent scaled back to fewer than 10 directors. By May 2001, almost forty percent of first-section Tokyo Stock

\footnotetext{
${ }^{16}$ Corporate Governance Comm., Corporate Governance Forum of Japan, Corporate Governance Principles-A Japanese View 41-42 (1998).

${ }^{17}$ Tokyo Stock Exchange, Results of Corporate Governance Survey, Nov. 30, 2000 (in Japanese).
} 
Exchange firms had added outside directors to their boards. ${ }^{18}$ For reasons we will discuss below, it is safe to assume that a significant percentage of these new outside directors are not truly independent of the firms on whose boards they serve. Nonetheless, the move to open the board to members other than career-long employees of the firm is potentially a significant step for Japanese firms.

In concert with reductions in board size, many corporations informally added a new corporate organ -- the executive officer. Until a 2002 amendment, Japanese corporate law did not contemplate a distinction between the positions of officer and director, because, as noted above, virtually all directors were in fact actively involved in management. In 1997, Sony created the informal position of executive officer, reflecting the parallel addition of outside directors to its board. Two years later, the position had become a fixture at over 200 firms. ${ }^{19}$ The 2002 reform, by creating the corporate officer, brought formal corporate law in line with the existing practice. ${ }^{20}$ This separation, by allowing the lodging of discretion in executive officers and casting the board of directors as monitors, is an attempt to separate monitoring and decision making functions and thereby strengthen the supervisory - monitoring - role of the board.

The last ten years' emphasis on corporate law and governance reform is a product of changes both in the macro economy and the political economy of Japan. The Commercial Code has traditionally contained "surprisingly paternalistic, archaic and impractical concepts, ${ }^{, 21}$ particularly in relation to corporate finance and organizational

\footnotetext{
${ }^{18}$ Shagai torishimariyaku 38\% ga sennin [38 Percent of Firms Choose Outside Directors], Nihon keizai shimbun, June 16, 2001, at 1.

${ }^{19}$ Curtis J. Milhaupt, Creative Norm Destruction: The Evolution of Nonlegal Rules in Japanese Corporate Governance, 149 U. Pa. L. Rev. 2083 (2001).

${ }^{20}$ Special Exception Law, Arts. 21-5(1).

${ }^{21}$ Kenichi Osugi \& Anthony Zaloom, Recent Amendments to Japan's Company Law: Drastic Overhaul or Just Tinkering? Unpublished manuscript (2002).
} 
structures. To cite just a few examples, until recently, repurchase of a company's own stock was prohibited except in narrowly defined circumstances, limitations were placed on the type of equity a company could issue, and holding companies were banned. These constraints were designed to protect creditors or were installed in the post-World War II period to prevent the re-emergence of the zaibatsu conglomerates that dominated the prewar economy. Yet they lent a highly formalistic and rigid cast to the corporate law. Its most severe critics called the Code's pervasive restrictions "senseless."22

Whether senseless or not, however, these restrictions had little impact on Japanese economic activity for most of the post-war period. Because bank lending was the dominant mode of corporate finance in the heyday of Japanese corporate governance, the Code's strict restrictions on equity finance techniques and its emphasis on technical creditor protections posed little obstacle to firms. Some scholars have even argued that a relatively mechanical, ex ante rule-oriented approach to corporate law complemented Japan's small judiciary and accounting profession in the immediate post-war period. ${ }^{23}$

Moreover, during the high economic growth period--when industrial organization was framed by the bank-centered keirets $u$ groups and the main bank system was thought to constrain managerial conduct, at least in poor financial states--little attention was paid to how well prosaic corporate actors such as boards, auditors and shareholders were

\footnotetext{
${ }^{22}$ J. Mark Ramseyer \& Minoru Nakazato, Japanese Law: An Economic Approach (1999); See also Osugi \& Zaloom, supra note 21 .

${ }^{23}$ Hideki Kanda \& Tomotaka Fujita, Kabushiki kaisha ho no tokushitsu, tayosei, henka [Features, Variety and Evolution of Stock Corporation Statutes], in Kaisha ho no keizaigaku (Yoshiro Miwa et al. eds 1998).

By contrast, flexible and permissive corporate laws empowering boards to engage in any lawful activity, subject only to the constraints of fiduciary standards applied ex post by courts to police selfish or grossly inattentive managerial behavior - characteristics of U.S. corporate law (see, e.g., William B. Chandler III \& Leo E. Strine, Jr., The New Federalism of the American Corporate Governance System: Preliminary Reflections of Two Residents of One Small State, 152 U Pa. L. Rev. (forthcoming 2003)) complement a fairly robust financial disclosure regime and an expansive legal system, featuring a large legal profession, a judiciary comfortable with the application of broad standards as opposed to narrow rules, and a procedural environment replete with procedural mechanisms to promote private litigation as a tool of enforcement.
} 
responding to agency problems within the firm because, in Aoki's J-form governance, these actors had little role to play in the governance structure. Japanese corporate law at the time certainly did not stand in the way of, and at the margins may actually have facilitated, the extra-legal monitoring mechanisms that characterized Japanese corporate governance in its heyday. ${ }^{24}$

The irrelevance of the corporate law (at worst) or the complementary fit between the corporate law and related enforcement institutions of postwar Japanese corporate governance (at best) came to an end in the 1990s. For many large firms, bank lending by that time had been replaced by the external capital market or by internally generated funding. At the same time, serious nonperforming loan problems in the banking sector disabled the central mechanisms of the main bank system of monitoring. The contribution of Silicon Valley to U.S. economic success in the 1990s, fuelled by stock options and innovative organization and contractual mechanisms not available under Japanese law, confronted the Japanese with a stark indication of the rigidities of their own legal system. Perhaps most importantly, as the Japanese economy's swoon continued and the main banks' monitoring role retreated, the corporate law's constraints on organizational form and corporate finance, latent in the main bank era but now patent in restricting an internal response to the governance vacuum, placed a serious drag on desperately needed corporate restructuring.

As corporate managers became increasingly conscious of the organizational straightjacket imposed by the corporate law, particularly in comparison to U.S. firms, the political economy of corporate law reform changed significantly. Or to put it differently,

\footnotetext{
${ }^{24}$ Curtis J. Milhaupt, A Relational Theory of Japanese Corporate Governance: Contract, Culture, and the Rule of Law, 37 Harv. Int'l L.J. 3 (1996).
} 
the market for the production of corporate law in Japan became much more competitive. Throughout the postwar period, Commercial Code reform was the province of a small coterie of legal scholars and Ministry of Justice officials, who convened a Legislative Reform Council to study — often for years - the propriety of potential corporate law amendments. Under this process, the law changed slowly and seldom in response to the exigencies of the market. In the words of one scholar, much Japanese corporate law reform over the past century was "policy pushed," rather than "demand pulled.",25

Beginning with a 1997 amendment to permit the issuance of stock options, however, the corporate law reform process changed significantly. Jump-starting Japan's highly underdeveloped venture capital industry, among other exigencies, precluded resort to the traditional amendment process to relax restrictions on stock options. The stock option amendment was initiated by politicians acting at the behest of the business community, rather than by bureaucrats working through the traditional, ponderous amendment process. ${ }^{26}$ Since then, the business community, working through their political allies in the ruling Liberal Democratic Party, has had a much larger voice in the corporate law reform process. ${ }^{27}$ Other examples of direct business and political input in the production of corporate law include a 2001 amendment permitting firms to limit the personal liability of directors, and withdrawal of a Ministry of Justice draft amendment requiring the appointment of at least one outside director to the board of large corporations.

\footnotetext{
${ }^{25}$ Zenichi Shishido, Reform in Japanese Corporate Law and Corporate Governance: Current Changes in Historical Perspective, 49 Am. J. Comp. L. 653 (1999).

${ }^{26}$ Kanda, supra note 11 .

${ }^{27}$ For example, in public comments the chairman of the Liberal Democratic Party's Subcommittee on Commercial Law, Seiichi Ota, leaves no doubt that his subcommittee placed priority on ensuring that the business community's views were reflected in recent Commercial Code amendments. See Seiichi Ota, "Sentakusei" saiyo ga kansayaku seido wo tsuyoku suru [Adoption of the "Elective System" Will Strengthen the Statutory Auditor System], 95 Torishimariyaku no homu 4-7 (2002).
} 
In addition to politicians and business groups, the Ministry of Economy, Trade and Industry (METI, the successor to the Ministry of International Trade and Industry, or MITI) has also become actively involved in corporate governance reform. Concern about the international competitiveness of Japanese firms and frustration over the failure of monetary and fiscal policy to restore the country's economic health motivated the ministry to turn its focus to corporate governance. It has supported a variety of marketoriented, flexibility-enhancing institutional changes in recent years.

Thus, in effect, the traditional Legislative Reform Council now has active competitors in the corporate law reform process: politicians working closely with business interests, and METI. One result of this competitive pressure is more "demand driven" corporate law amendments, made at an accelerated pace. As we will see, the 2002 enabling approach to corporate governance is a byproduct of this new environment for the production of corporate law in Japan.

\section{The 2002 Reform}

The 2002 reform allows "large" firms ${ }^{28}$ to adopt a U.S. style "committee system" for corporate governance beginning April 1, 2003. ${ }^{29}$ Adopting firms abolish the board of statutory audit and establish committees of the board for audit, nomination and compensation. Each committee must have at least three members, a majority of whom are "outside" directors. However, as we will discuss in more detail below, the Commercial Code's definition of outside director is broad enough to include employees

\footnotetext{
28 "Large" firms are those capitalized at 500 million yen or more, or with debt in excess of 20 billion yen. "Constructive large firms" (capitalized in excess of 100 million yen with an audit structure equivalent to that used by large firms) are also eligible to adopt the committee system. We estimate the number of firms eligible to adopt the board committee system to be roughly 3500 , including more than 3000 publicly listed firms.

${ }^{29}$ Special Exception Law, Arts. 21-5 et seq.
} 
of a parent company and sibling firms under a common parent. Adopting firms must appoint officers, including at least one "representative officer" with authority to act for the firm - essentially a CEO. The board is to monitor the business and affairs of the company, as executed by the officers. The term of office for both directors and officers is set at one year. Firms that do not opt into the new committee system continue to operate under essentially the same governance structure as before: they retain the statutory auditor system (subject to various amendments designed to bolster its effectiveness) and may, but are not required to, have outside directors on the board. ${ }^{30}$

As we noted in the Introduction, this enabling approach to corporate governance reform is distinctive; other countries seeking to improve their governance institutions have chosen blanket, mandatory reforms applicable to all large firms. The explanation for the adoption of an enabling approach in Japan is lack of consensus on the direction of reform among groups with newfound influence in the corporate law process, reflecting the new political dynamics we have just described. While, as we have shown, the board and statutory auditor system were a focal point for reform in the $1990 \mathrm{~s},{ }^{31}$ no single model of reform gained ascendance. The Ministry of Justice was a proponent of "U.S.-style" board reform. $^{32}$ Its initial proposal would have permitted firms to replace the auditor system with three mandatory committees of the board, and required that all large

\footnotetext{
${ }^{30}$ Certain firms retaining the statutory auditor system are eligible to adopt one structural innovation: Firms with boards larger than 10 members, at least one of whom is an outside director, may establish an "Important Asset Committee" to handle a subset of issues that would otherwise be decided by the board. Until the 2002 reform, Japanese corporate law prohibited boards from delegating "important" matters.

31 And in fact, by the late 1990s important reforms were taking place outside the corporate law amendment process, as firms began shrinking the size of the board and delegating managerial roles to de facto officers.

${ }^{32}$ See Mashafumi Nakahigashi, Corporate Governance in Japan: Financial Information and Auditing System, unpublished working paper, at 15-16 (describing the Ministry of Justice as "pursuing a 'full American model'" in corporate governance reform).
} 
firms have at least one outside director. This proposal met with substantial

resistance from the business community on two grounds: Some objected to the idea that any particular board structure should be legislatively mandated; rather, firms should be allowed to establish only those committees they desired. More widespread criticism focused on the proposed requirement that all large firms have outside directors. Common charges against such a requirement are that outside directors are not well suited to perform a useful role in highly relational Japanese corporate affairs, and that finding suitable outside directors will be extremely difficult given the lack of experience with the practice. Reflecting these sentiments, the Ministry of Finance spoke out against any imposition of the U.S. model on Japanese firms. ${ }^{33}$

Resistance to the Ministry of Justice initiative partially took the form of counterproposals, backed by the political allies of Keidanren, the big business lobby, to reinforce the statutory auditor system. Preservation of this system, even at the cost of its invigoration, was tacitly understood as the best way to parry the thrust toward convergence with the U.S. model, and especially the appointment of outside directors to the board. ${ }^{34}$ METI and others promoted the conceptual advantages of allowing firms to adopt the governance structure best suited to their individual needs rather than imposing a uniform structure—an approach whose

\footnotetext{
${ }^{33}$ See Barney Jopson, and David Pilling, U.S. Corporate Governance not Suited to Japan, Says Ministry, Financial Times, June 21, 2003.

${ }^{34}$ Even more pressing for the business community was securing shelter from the explosion of derivative litigation that followed from the 1993 amendment reducing the filing fees for shareholder suits. They achieved this goal in the 2001 reforms, which allow shareholders to limit director liability to a multiple of annual compensation ranging from two to six times, depending on the director's relationship to the firm. Interestingly, this approach - capping rather than eliminating director personal liability - was originally proposed by the American Law Institute's Corporate Governance Project prior to Delaware's authorizing corporations to eliminate liability entirely through the enactment of Del Code $\S 102(b)(7)$. See American Law Institute, Principles of Corporate Governance §7.19.
} 
attractiveness increased following the U.S. scandals. Thus, the final version of the 2002 reform contains something for everyone: no requirement that all firms appoint outside directors, amendments to buttress the statutory auditor system (thereby possibly diminishing the prospects of its elimination in the future), and a strong endorsement of the concept of choice, including the option of abandoning traditional Japanese institutions in favor of the U.S.-style board structure. The approach is distinctive, but that distinctiveness owes much to the need to cabin the scope of reform within prevailing political and social limitations.

\section{Adopting Firms}

Firms opt into the new board committee system by amending their certificate of incorporation, a process requiring shareholder approval. Thus, the 2003 annual shareholders meetings (typically held in June) presented the first opportunity for Japanese firms to adopt the new system. We present complete data on adoptions through March 31 , 2004, encompassing all adopting firms in the first round. ${ }^{35}$

In total, seventy one firms adopted the committee system in the first round. ${ }^{36}$ Of these, forty five are listed companies. The total represents only a tiny fraction-less than three percent--of eligible firms. Yet it is important to evaluate this number in context. The adopting firms, of course, reflect simply the first round of adoptions in a process that will continue indefinitely; additional firms can be expected to follow the early adopters. ${ }^{37}$ Moreover, the number of adopting firms, though small, substantially exceeded

\footnotetext{
${ }^{35}$ Most Japanese firms end their fiscal year on March 31 and hold their annual shareholders meeting in June. Our study also captures those eligible firms whose fiscal year ends on December 31, which had until March 31, 2004 to hold their 2003 annual shareholders meeting.

${ }^{36}$ Actually, the total number of adoptions was slightly higher; mergers of several adopting firms within the Nomura group left 71 firms with the board committee structure as of March 31, 2004.

${ }^{37}$ As of March 2004, fifteen firms have announced that they plan to adopt the committee system at their 2004 annual shareholders meeting.
} 
expectations. Just a few months prior to the 2003 annual shareholder season,

commentators predicted that only three or four firms would adopt the committee

system. ${ }^{38}$ Thus, from the Japanese perspective, the number of adoptions presents

something of a surprise on the high side. Finally, recall the timing of this reform: The

2002 amendment to the Commercial Code that enabled choice in the selection of board

structure occurred in the midst of worldwide fallout from the Enron and WorldCom

scandals. Ironically, at the precise moment Japanese firms were given the option of

adopting "US-style" corporate governance (and that is how the new system is commonly,

if controversially, referred to in Japan), the United States was undergoing its most serious

corporate governance crisis in at least a generation. This, together with uncertainty about

the stability of the political balance reflected in the 2002 amendment, may have slowed

the migration to the new governance structure. ${ }^{39}$

Table 2 presents the name and industrial classification of adopting firms.

INSERT TABLE 2

Several interesting characteristics of the adopting firms are evident from the table.

First, although we noted above that the number of adoptions was surprisingly large to

\footnotetext{
${ }^{38}$ See, e.g., Miwa Suzuki, Experts Doubt Many Firms to Follow Sony and Adopt U.S.-Style Structure, Agence France-Presse, Jan. 29, 2003.

${ }^{39}$ The strategy of allowing a choice between two quite different approaches to corporate governance in order to resolve political conflict between backers of the two approaches finds something of a recent parallel in the ultimate resolution of the 15 year odyssey of the European Union's Thirteenth Directive on Takeovers. The conflict between pro- and anti-takeover forces came to a head with the European Commission's October 2002 proposed directive, which both prohibited post-bid defensive tactics and imposed a break-through rule that would limit the operation of structural defenses like voting caps that operate to block takeovers even without post-bid defensive tactics. The Directive finally approved by the European Parliament 14 months later retains both the prohibition of defensive tactics and the break-through rule, but allows individual states to opt out of either or both. If a state does opt out, the Directive allows individual companies governed by that state's corporate law the right to adopt the more restrictive rules by a vote of the general meeting. Rolph Skog, The Takeover Directive-An Endless Saga, European Bus. L. Rev. (April 2002), traces the Directive's tortured history through its 2001 surprise defeat by a tie vote in the European Parliament, despite an agreed text following conciliation, at the urgings of the German government. This unexpected event gave rise to the final round of revisions described above.
} 
Japanese observers, the aggregate number of adoptions is somewhat misleading. The total of seventy one firms includes the Nomura financial holding company and thirteen privately held subsidiaries, as well as Hitachi Ltd. and twenty one of its affiliates. Excluding these related-firm overlaps, the number of adoptions falls by about half. Second, the absence of companies affiliated with bank-centered keiretsu, the dominant feature of postwar Japanese industrial organization in its heyday, is striking. Indeed, adopting firms are largely characterized by their independence from traditional patterns of Japanese industrial organization. Sony and Orix, for example, are widely perceived as mavericks in the Japanese business community. Nojima and Gakkyusha are relatively new start ups, at least by Japanese standards. The Hitachi companies obviously form an industrial group, but there is no main bank at its center, and the individual companies in the group are affiliated with several different bank-centered keiretsu. The cluster of Nomura affiliates is the result of recent reforms permitting holding companies in the financial industry. As such, the Nomura group does not constitute a traditional keiretsu.

Third, adoptions are concentrated in several industries. Controlling for related firm overlaps, by sector, the largest number of adoptions is in the electronics sector. This group includes global players Sony, Toshiba and Mitsubishi Electric. There are also clusters of adoptions in the finance and retail industries, two troubled sectors of the economy. Particularly noteworthy is the adoption by Resona, a troubled bank that was recently recapitalized with public funds. Four other banking subsidiaries of Resona 
Holdings, as well as Ashikaga Bank, another distressed bank currently under government control, have announced that they will adopt the committee system in $2004 .^{40}$

Table 3 indicates that many adopting firms have substantial foreign ownership. Nineteen of the adopting firms (56 percent of the firms that are not subsidiaries of Toshiba or Nomura) have foreign ownership in excess of 18 percent. These include distressed companies that attracted foreign owners, global players whose stock has attracted a substantial following among foreign portfolio investors, and Japanese firms acquired by foreign corporations as part of a global expansion strategy. The first group includes Seiyu, a large retail chain now controlled by Wal-Mart, Tokyo Star Bank, the successor to a failed bank acquired by Lone Star, and Manulife, which came under the ownership of the Canadian insurer after its Japanese joint venture partner collapsed. The global players among the adopting firms are epitomized by Sony, whose stock is widely held by foreigners. The third group includes Japan Telecom Holdings (recently renamed Vodaphone Holdings), whose leading shareholder is Vodaphone Plc of Britain.

\section{INSERT TABLE 3}

Another noteworthy feature of the adopting firms is that cross-listing of securities on U.S. securities exchanges does not appear to be highly predictive of the decision to switch to the board/committee system. Only four of thirty three (13\%) Japanese firms with ADRs listed on the NYSE or the NASDQ have adopted the committee system. ${ }^{41}$ This is surprising, because one would expect that firms seeking a following among U.S.

\footnotetext{
${ }^{40}$ One possible explanation for the adoption of the committee system by government officials managing these distressed banks is that the board committee structure is often said to have a higher degree of transparency than the traditional Japanese board, and "transparency" is currently something of a buzz word in Japanese governmental circles.

${ }^{41}$ All four are NYSE listed firms: Hitachi, Ltd., Nomura Holdings, Orix, and Sony. For a list of Japanese firms listed on NYSE, see http://www.nyse.com/listed/7.html. For a list of Japanese firms listed on NASDAQ, see http://www.nasdaq.com/asp/NonUsOutput.asp?page $=J \&$.
} 
shareholders would be most likely to adopt U.S.-style governance mechanisms.

However, there may be two reasons for this counterintuitive result. First, the Sarbanes-

Oxley Act (which applies to foreign private issuers whose securities are traded on U.S.

exchanges or NASDAQ) actually may dampen the incentive for Japanese firms to switch

to the committee system. Sarbanes Oxley mandates that all of the members of the audit

committee of a public company's board be independent. But the SEC's regulations

implementing Sarbanes-Oxley grandfather existing substitutes for audit committees, such

as the Japanese statutory auditor, currently recognized under foreign legal systems.

Under Japanese law, currently only one member of the board of audit must be an outsider

(and only a majority in 2005). Thus, it is easier for Japanese firms with shares listed on

U.S. exchanges to satisfy the federal requirements by retaining the traditional auditor

system. Second, seven high profile Japanese firms have cross listed their securities in the

United States through so-called "Level III facilities," meaning that they are subject to the

same federal securities disclosure and enforcement regime as publicly traded U.S.

firms. ${ }^{42}$ If, as we discuss in the next section, one strategy for adopting the committee

system is to signal adherence to global (or at least U.S.) best practices in corporate

\footnotetext{
${ }^{42}$ Crosswave Communications, Hitachi Ltd., Internet Interactive Japan, Kyocera, Nissin, TDK, Toyota, and Trend Micro. Foreign firms can cross-list their securities in the United States in three ways: In a "Level I" facility, a firm simply establishes a depositary facility in the U.S. so that its shares can trade on the pink sheets. In a "Level II" facility, the foreign firm establishes a depositary facility and lists its ADRs on a U.S. exchange or Nasdaq. In a "Level III" facility, a foreign firm not only establishes a depositary facility and lists its stock on a U.S. securities exchange or Nasdaq, but also conducts a public offering of its securities in the United States. A Level I facility imposes no U.S. new disclosure obligations or enforcement risks on the foreign firm. Firms with Level II facilities are subject to streamlined U.S. disclosure obligations and certain enforcement risks under the U.S. securities laws. Only a Level III facility subjects the foreign issuer to the full panoply of disclosure and liability rules applicable to U.S. public firms.
} 
governance, then these Japanese firms arguably have already done so by establishing Level III facilities, and may gain little extra by adopting the board/committee system. ${ }^{43}$

Finally, Table 4 shows the board structure of the adopting firms. As would be expected given that at least two outside directors are needed to serve on the required committees, adopting firms tend to have significantly more outside directors than listed companies in general. The table shows that outside directors comprise between one-third and two-thirds of the boards of adopting firms. By contrast, only one-quarter of all Tokyo Stock Exchange-listed firms have outside directors on their boards. Of these, half have just one outside director, and outside directors comprise less than twenty percent of the total number of directors. ${ }^{44}$ However, caution is warranted in discussing outside directors on Japanese boards. Under Japanese corporate law, an "outside" directorinstructively, the term "independent" is not used--can be affiliated with a major shareholder, parent company, or another subsidiary of the parent company. ${ }^{45}$ Thus, virtually all of the "outside directors" of the Hitachi group companies are affiliated with Hitachi Ltd., and most of the outside directors of the Nomura subsidiaries are affiliated with Nomura Holdings or Nomura Securities. ${ }^{46}$

\section{INSERT TABLE 4}

\footnotetext{
${ }^{43}$ Of the seven firms with Level III facilities, only Hitachi has adopted the new committee system. As we explore TAN 67-70 infra, signaling is not the principal reason for Hitachi's adoption.

${ }_{44}$ See More Listed Companies Inviting Outside Directors on Board, NikkeiNet Interactive, Oct. 13, 2003, available at http://www.nni.nikkei.co.jp (reporting results of recent survey of 2100 TSE-listed firms).

${ }^{45}$ See Commercial Code art. 188 (defining outside director as a "director who is not involved in the management of the company, nor is currently or at any time has been an executive director, manager or employee of the firm or any of its subsidiaries.")

${ }^{46}$ See Yasuhiro Yamada, Iinkaito setchi geisha no unyo jitsumu [Operation of Companies Adopting the Committee System], 478 Kansayaku 28, 31 (2003) (responses were received from 29 group companies and 13 non-group companies).
} 


\section{Strategies of Choice}

The next step in our analysis is to examine a range of possible explanations for a company's decision to adopt the board/committee structure. We recognize that the results of the first round of adoptions are only suggestive of the range of company strategies that may have been at work and that other strategies may arise as experience with the 2002 reform accumulates; however, they do help frame the questions that further experience may answer and provide a set of hypotheses that can be tentatively assessed by means of an event study.

\section{A. The Simple Story: Board Centered Governance is Better}

The most straightforward explanation for a Japanese company adopting a board centered governance structure is the belief, animating the Ministry of Justice's efforts both to allow replacement of the statutory auditor system with a board/committee structure and to require that large firms have at least one outside director, ${ }^{47}$ that the Anglo-Saxon governance structure was better suited to the current economic environment and therefore reform would lead to better corporate performance. From this perspective, companies would adopt the board committee structure to improve their performance.

The difficulty with this analysis is the data. Studies of governance differences within developed countries in general, and of board composition in particular, do not show that "better" governance results in better performance. ${ }^{48}$ Only with respect to takeover defenses does there seem to be clear evidence that governance matters. ${ }^{49}$

\footnotetext{
${ }^{47}$ See TAN 32 supra.

${ }^{48}$ See, e.g., Sanjai Bhagat \& Bernard Black, The Uncertain Relationship Between Board Composition and Firm Performance, 27 J.Corp. L. 231 (2002). For Japan, Yoshiro Miwa and Mark Ramseyer report that Japanese companies with outside directors prior to the 2002 reform do not show better performance than
} 
An alternative approach to evaluating the impact of governance on performance is more favorable to the link between the two. There is a large literature that demonstrates an increase in share price associated with the listing of non-U.S. stocks on U.S. stock exchanges. ${ }^{50}$ While U.S. law and listing requirements do not require a board/committee structure in order for a company's stock to be listed on a U.S. exchange (at least if the company's home country recognizes a substitute for the audit committee), listing does impose an important range of U.S. securities law requirements, including especially private and public enforcement and increased disclosure. ${ }^{51}$ Most recently, studies have shown that the increase in value associated with cross-listing is associated with the resulting greater protection of minority shareholders against controlling shareholders. For example, non-U.S. firms that list on U.S. exchanges have voting premiums - the difference between the stock prices of high and low voting stock - that are 47 percent lower than non cross-listing non-U.S. firms. ${ }^{52}$

those without outside directors. Yoshiro Miwa \& J. Mark Ramsayer, Who Appoints Them, What Do They Do? Evidence on Outside Directors From Japan, Harvard Law and Econ. Disc. Paper (January 2004). ${ }^{49}$ See Paul Gompers, Joy Ishii \& Andrew Metrick, Corporate Governance and Equity Prices, 118 Q. J. Econ. 107 (2003); Lucian Ayre Bebchuk, John C. Coates IV \& Guhan Subramanian, The Powerful Antitakeover Force of Staggered Boards: Theory, Evidence, and Policy, 54 Stan. L. Rev. 887 (2002).

${ }^{50}$ See, e.g., Darius P. Miller, The Market Reaction to International Cross-Listings: Evidence from Depository Receipts, 51 J. Fin. Econ. 103 (1999).

${ }^{51}$ See, e.g., John C. Coffee Jr., The Future as History: The Prospects For Global Convergence in Corporate Governance and its Implications, 93 Nw. L.Rev. 641 (1999) (legal effects of cross-listing); Mark H. Lang, Karl V. Kims \& Darius Miller, ADRs, Analysts, and Accuracy: Does Cross-Listing in the U.S. Improve a Firm's Information Environment and Increase Market Value? available at http://papers.ssrn.com/sol3/papers.cfm?abstract_id=304623 (April 2002) (forthcoming, Journal of Accounting Research) (firms that cross-list on U.S. exchanges have greater analyst coverage and increased forecast accuracy that is associated with increased firm value on cross-listing). Studies show that the largest positive market reactions to cross-listings occur when a foreign firm establishes a Level III facility. See Miller, supra note 50.

${ }^{52}$ Craig Doidge, U.S. Cross-listings and the Private Benefits of Control: Evidence from Dual Class Stock, available at http://papers.ssrn.com/sol3/papers.cfm?abstract_id=373740 (January 2003). See William A. Reese Jr. \& Michael Weisbach, Protection of Minority Shareholder Interests, Cross-Listings in the United States, and Subsequent Equity Offerings, 66 J.Fin. Econ. 65 (2002); Craig Doidge, Andrew Karolyi \& Rene M. Stulz, Why Are Foreign Firms Listed in the U.S. Worth More?, available at http://papers.ssrn.com/sol3/papers.cfm?abstract_id=285337 (September 2001). 
This link between governance and minority protection has implications for the role of outside directors and, in turn, for the choice of governance structure now available to Japanese companies. Black, Jang and Kim find that in Korea, controlling for all other governance characteristics, large firms with 50 percent outside directors have a stock price 40 percent higher than firms without an outside board. ${ }^{53}$ The authors interpret their results as showing the importance of outside directors in controlling tunneling by controlling shareholders: "The most likely reason why outside directors add value is that they may control self-dealing by controlling shareholders." ${ }^{54}$

Because Japan, unlike many developing countries as well as the Scandinavian and many European countries, is not characterized by controlling shareholder capital structures, Japanese firms are not subject to widespread controlling shareholder tunneling. However, Japanese firms may be subject to a different type of diversion of resources away from shareholders, what we will call "stakeholder tunneling." It has been commonplace to characterize Japanese firms as committed to maximizing something other than shareholder value, most commonly highlighted are employee interests. ${ }^{55}$ Examples include maintaining employment levels in the face of serious financial difficulties, and pursuit of expansion without careful regard to profitability. A majority of outside directors serving on committees adopted pursuant to the 2002 amendment may serve the same function with respect to stakeholder tunneling in Japan that outside directors served with respect to controlling shareholder tunneling in Korea -- outside

\footnotetext{
${ }^{53}$ Black, Jang \& Kim, supra note 5.

${ }^{54}$ Id. at 48 . Making the same point a little differently, the authors state: "We do not find strong evidence that better governed firms are more profitable or pay higher dividends. We do find that investors value the same earnings or the same dividends more highly for better governed firms." Id. at 6.

${ }^{55}$ For the classic formulation of this view, see James Abbeglen \& George Stalk, Jr., Kaisha: The Japanese Corporation (1985). But see Steven Kaplan \& J. Mark Ramseyer, Those Japanese Firms with Their Disdain for Shareholders: Another Fable for the Academy, 74 Wash U. L.Q. 403 (1996) (reporting results of empirical studies indicating that Japanese managers do not ignore stock price or profits).
} 
directors, not dependent on either the controlling shareholder or committed to other stakeholders - can prevent resources from being diverted from shareholders. Thus, a Japanese company may adopt a board/committee structure as either a signaling or a bonding strategy. For companies that do not engage in stakeholder tunneling, adopting the board/committee structure signals the existence of this otherwise difficult-to-observe characteristic. For firms that wish to change their behavior, the adoption bonds their future conduct. In either event, the argument runs, less of the firm's earnings are diverted with a resulting increase in share price per unit of earnings.

The problem with this strategy, at least at this point, is that neither the signal nor the bond is likely to be credible. First, as we have previously pointed out, the 2002 amendment requires outside directors but does not demand independence. Thus, the mere adoption of a board/committee structure may not result in the discipline apparently experienced in Korea. Second, the role of the outside directors may be different with respect to controlling shareholder tunneling and stakeholder tunneling. Disapproval of a controlling shareholder misappropriating corporate resources is less likely to be culturally embedded (as opposed to being caused by a lack of political or institutional resources needed to stop it) than stakeholder tunneling. Stakeholder tunneling, in contrast, is commonly said to be a cultural characteristic of Japan, or at least a function of the incentive structures within which Japanese managers operate. ${ }^{56}$ If outside directors share the same cultural commitment to stakeholder tunneling (or the same incentive structures) as do the insiders, little changes as a result of the shift to outsiders. ${ }^{57}$ Of course, cultures

\footnotetext{
${ }^{56}$ See TAN 15-16 supra.

${ }^{57}$ Indeed, one recent study indicates that the presence of outside directors on Japanese boards actually reduces the sensitivity of managerial turnover to performance. See Naohito Abe, Managerial Incentive
} 
(and incentives) change, sometimes quickly. And outside directors, because they open the company to outside influence, may turn out to be the hydraulics of change even if they are not its cause.

\section{B. The Endogeneity of Governance Structure}

A second assessment of the initial adoption pattern is agnostic concerning the comparative effectiveness of the Japanese statutory auditor system and the Anglo-Saxon board committee structure. Building on Harold Demsetz and Kenneth Lehn's early argument that corporate ownership structure is endogenous, ${ }^{58}$ Miwa and Ramseyer argue that the appointment of outside directors is also endogenous, driven by each firm's particular industrial organization. ${ }^{59}$ As Aoki has stressed repeatedly, from this perspective the structure of Japanese corporate governance is driven by the substantive characteristics of Japanese production. ${ }^{60}$ What we have called stakeholder tunneling in Aoki's view is just the reflection of a manufacturing system characterized by horizontally organized team production in industries characterized by linear change that gives a long useful life to large investment in team-oriented human capital team. And as Aoki himself recognized, ${ }^{61}$ the Japanese governance system is not well suited to industries characterized by rapid, non-linear change. Such competence destroying change reduces the useful life of human capital investment and highlights the need for a governance structure that is highly mutable - able to quickly respond to changes in the economic

Mechanisms and Turnover of Company Presidents and Directors in Japan, KDI School of Public Policy and Management Working Paper No. 03-08 (2003).

${ }^{58}$ Harold Demsetz \& Kenneth Lehn, The Structure of Corporate Ownership, 93 J. Pol. Econ. 1155 (1985).

${ }^{59}$ Miwa \& Ramseyer, supra note 48.

${ }^{60}$ See note 2 supra; Ronald J. Gilson \& Mark Roe, Understanding the Japanese Keiretsu: Overlaps Between Corporate Governance and Industrial Organization, 102 Yale L. J. 871 (1993).

${ }^{61}$ Aoki, supra note 2 (J Econ. Lit.). 
environment. ${ }^{62}$ Outside directors, without a lifetime investment in a company's particular infrastructure, are arguably faster at responding to changes that dictate disruptive adaptation. From this perspective, board composition will differ between companies and between industries. As Miwa and Ramseyer demonstrate for the 19861994 period, some companies appoint outside directors and others do not; the choice of governance structures is in their view efficiency driven.

There is some support for this choice strategy in the preliminary results. The largest concentration of adopting companies is in the electronics industry, including global players like Sony and Toshiba. Japanese manufacturing, at the core of Aoki's endogeneity argument, turned out to be less tightly tied to the characteristics of Japanese governance than Aoki believed, with the result than other countries could imitate the manufacturing techniques without adopting the governance-based stakeholder tunneling structure. ${ }^{63}$ Acknowledging this greater degree of freedom, Japanese companies themselves successfully moved much manufacturing offshore without exporting lifetime employment and the seniority-based promotion system. Finally, the rate of change in the electronics industry accelerated, driven by foreign companies that were highly entrepreneurial, often venture capital financed, with governance structures that were highly mutable; Japanese companies had to respond. ${ }^{64}$

\footnotetext{
${ }^{62}$ See Gilson, supra note 9 (Political Ecology).

${ }^{63}$ Charles Sabel, Ungoverned Production: An American View of the Novel Universalism of Japanese Production Methods, Law and Economics Center Working Paper, Columbia Law School (Feb. 1996); Susan Helper, John MacDuffie \& Charles Sabel, The Boundaries of the Firm as a Design Problem, Law and Economics Center Working Paper, Columbia Law School (Feb. 1997).

${ }^{64}$ See, e.g., Colin Crouch \& Wolfgang Streek, Introduction: The Future of Capitalist Diversity, in Political Economy of Modern Capitalism: Mapping Convergence and Diversity 1 (Colin Crouch \& Wolfgang Streek eds. 1997): "[A]ccelerated technological change, renewed price competition and the globalization of financial markets have combined to produce a world economy in which a premium seems to be placed on speed of reaction: on rapid product change and an ability to cut costs fast. ... The destruction or devaluation
} 
The concentration of adoptions by companies in troubled industries and industries with large foreign investment also are consistent with an endogeneity driven explanation. Troubled companies in particular may require an external source of change to overcome existing management's stake in the status quo, which explains the overlap between these two categories - troubled companies and companies with large foreign ownership. The recent account of U.S. private equity investor Ripplewood's transformation of Long Term Capital Bank of Japan and the initial public offering of LTCB's rehabilitated successor (renamed Shinsei Bank) underscore both the impetus of failure and the critical role played by foreign control. ${ }^{65}$

From an endogeneity perspective, the 2002 amendment is far less radical than it might first appear. To be sure, cultural conservatives might vigorously oppose even choice-based reform because a mandatory requirement of the traditional governance structure stands as something of a barrier to unwanted change. But to the extent that the 2002 amendment follows a U.S. lead, it is that of an earlier period. The traditional core of U.S. corporate governance law is the enabling concept - everything is available, nothing is required. The most recent cycle of U.S. corporate governance reform, however, both through Sarbanes-Oxley and the recent New York Stock Exchange and NASDAQ rules, are mandatory, especially with respect to board composition and committee structure. The nice irony is that the Japanese system has come to share

of national state capacity under globalization discriminates against national economies that are socially governed by politics at the national level."

${ }^{65}$ Gillian Tett, Saving the Sun (2003); Shinsei Sets Price for IPO, Wall St. J., Feb. 10, 2004 at C6. LTCB's successor, Shinsei Bank, has announced that it will adopt the committee system in June 2004. 
something of the core enabling concept of the traditional U.S. governance system, while the U.S. system has come to share more of the traditional mandatory Japanese system. ${ }^{66}$

\section{The Board Committee Structure as a Means to Organize Corporate Groups}

As we suggested in the Introduction, keiretsu firms may face higher barriers to change that reduce the attractiveness of the choice offered by the 2002 reform. Keiretsu firms obtain benefits from group affiliation that may be dissipated by devolution of important decisions to committees composed of outside board members. Moreover, alliances may simply be more difficult to form and maintain under U.S./U.K. governance structures. At the very least, the more collective decision making style of the groups may lead to initial delays in adoption of the new committee system, followed by a cascade of elections by group firms.

Yet the data from first round adoptions indicate that the new board/committee structure, at least in combination with the Commercial Code's expansive definition of "outside director," is sufficiently mutable to be attractive to at least some corporate groups. Since directors affiliated with parent and sibling firms are eligible to serve on the mandatory committees of audit, compensation and nomination, the new governance structure can be used to enhance group cohesion and to assert greater parent or lead company control over member firms. Indeed, both Hitachi and Nomura publicly stressed unifying and strengthening group management as the reason they adopted the committee system. Almost 93 percent of the "outside" directors of companies within the Nomura group are managers of Nomura Holdings or Nomura Securities, the core firm. ${ }^{67}$ Seventy

\footnotetext{
${ }^{66}$ See, e.g., Jesse Choper, John C. Coffee, Jr. \& Ronald J. Gilson, Cases and Materials on Corporation Law (6 ${ }^{\text {th }}$ ed. 2004); Roberta Romano, The Genius of American Corporate Law (1993).

${ }^{67}$ Kansa iinkai konwakai, Nomura Shoken gurupu kogaishagun ankeeto kekka [Results of Survey of Nomura Securities Group Subsidiaries], (Sept. 25, 2003).
} 
eight percent of the "outside" directors of Hitachi group companies are from Hitachi Ltd. ${ }^{68}$ In addition to the three mandatory committees, Hitachi Ltd. established a fourth committee of top executives described internally as a "'supreme' decision-making body that will formulate group business strategy. ${ }^{, 69}$ Thus, a second irony of the 2002 reform is that, while ostensibly designed to permit the adoption of "U.S.-style" corporate governance, it can also be used to strengthen corporate groups, one of the hallmarks of postwar Japanese corporate governance.

This mutability inherent in the new board/committee structure is supported by the data. Board composition among adopting firms is neatly bifurcated between group firms and independent firms. Group firms have "outside" directors affiliated with the group through employment or business ties; firms that are not part of a group have outside directors that can more properly be characterized as "independent." Of 42 adopting firms responding to a recent survey, 32.5 percent of the outside directors of group firms are managers of the parent firm, and 83.3 percent have business or financial ties to the firm on whose board they serve. The same survey showed that only 17.2 percent of the outside directors of non-group companies have business or financial ties to the firm on whose board they serve. The most common professions among these outside directors are manager of unaffiliated firms (36.2\%) and lawyer $(17.2 \%){ }^{70}$

\section{Indeterminacy}

\footnotetext{
${ }^{68}$ Kansa iinkai konwakai, Hitachi gurupu kogaishagun ankeeto kekka [Results of Survey of Hitachi Group Subsidiaries], (Sept. 25, 2003)

${ }^{69}$ Hitachi to Set Up Panel Focusing on Group Business Strategy, Nikkei Net Interactive, June 23, 2003, available at www.nni.nikkei.co.jp.

${ }^{70}$ Yasuhiro Yamada, Iinkaito setchi geisha no unyo jitsumu [Operation of Companies Adopting the Committee System], 478 Kansayaku 28, 31 (2003) (responses were received from 29 group companies and 13 independent companies).
} 
A final explanation for the overall array of adoptions we observe in the first round is simply indeterminacy; at least so far, we see not a distinct pattern of adoptions but the lack of a pattern. We have in mind here two points. First, patterns appear most clearly when a phenomenon has only a single cause. Our survey of possible motivations for Japanese company adoption of the board/committee structure does not assume that the motivations are mutually exclusive, either across the overall economy or within a single company. The result is that without a hypothesis about the relative weights of the explanations and their interaction, the only pattern observable may be Brownian motion. If this is correct, then pending deeper insight than we have now, analysis will have to be more focused, trying to explain the choices of a particular company or those that come to characterize a particular industry.

The second point is a political economy overlay. In the Introduction, we lightheartedly referred to Newton's evocatively conservative First Law of Motion: objects at rest tend to remain at rest. Completing the shift from physics to social dynamics by adding a political economy overlay - Newton with a Mancur Olson frosting - also suggests a significant level of indeterminacy, especially in the short run. Powerful interest groups with a substantial stake in the traditional governance structure have an interest in maintaining their own position even at the cost of reducing overall economic performance. $^{71}$ The shifts in political influence that gave rise to the 2002 reform, as we described in Section II, reflect the interaction between the forces of economic change and

\footnotetext{
${ }^{71}$ Olson, supra note 10.
} 
the resistance of those who will be disadvantaged by it. In the short run, the resulting boundary will shift, both by firm and industry, leaving a seemingly random pattern. ${ }^{72}$

\section{E. Market Reaction to Adoptions}

In an effort to distinguish which among these strategies was operative in the first round of adoptions following the 2002 reform, we attempted to gauge market reaction to the adoptions. Using well established event study methodology, ${ }^{73}$ we measured the stock price effects of the first public announcement that a firm intended to adopt the new committee system. We measured these effects for all publicly traded adopting firms for which we had data, ${ }^{74}$ other than the Hitachi affiliates - a total of twenty two firms. For this group, average abnormal returns to announcements were negative but not statistically significant.

Our earlier analysis suggests a number of reasons why the price effects of announcements of adoptions of the committee system should be insignificant for the group as a whole. First, the results are consistent with our hypothesis that the actual reforms in fact may be innocuous. Thus, independent of whether a meaningful committee system is in the abstract superior to traditional Japanese governance structures, the alternative offered by the 2002 reform, requiring only outside rather than independent directors, may be too watered down a version of the committee system to affect company value. The results are also consistent with the prior results of empirical tests of the

\footnotetext{
${ }^{72}$ It is interesting, for example, that firms in the financial industry comprise a significant number of adoptions, despite public statements by Ministry of Finance that U.S.-style corporate governance is not appropriate for Japan. See supra note 33.

${ }^{73}$ We calculated the average abnormal returns to first public announcements (by press release or publication in the Nikkei Shimbun, Japan's leading financial newspaper) of a corporation's intent to submit adoption of the committee system for approval at its next annual shareholders meeting. We estimated a statistical model using daily returns for 250 days preceding the announcement date. Since each of the 22 sample firm's announcements were made on a different calendar day, the likelihood that other information besides the announcement contributed to the stock price effects is reduced.

${ }^{74}$ Complete data were unavailable for Nissei, Gakkyusha, People, Japan Herald, and Silex Technology.
} 
valuation effects of independent directors. Other than in systems dominated by controlling shareholders, independent directors are not associated with statistically significant valuation effects. At least for the first round of adoptions, our results do not reflect gains from constraining the Japanese equivalent of controlling shareholder selfdealing - stakeholder tunneling.

Second, the absence of statistically significant valuation effects on adoption may reflect an anticipation phenomenon. Some companies may have informally adopted committee-like governance reform in advance of formal adoption, which captures most of the gain (or loss) from the governance changes made possible by the 2002 reforms. As a result, formal adoption of the committee system would not result in significant change in value.

In an effort to assess whether our results are influenced by some companies anticipating informally committee-like governance reform in advance of formal adoption, we divided the full sample into two sub-samples. The first (12 companies) is composed of companies with more than 20 percent foreign shareholders and which are active in international markets. The second (10 companies) is composed of companies with less than 20 percent foreign shareholders and largely domestic Japanese business. The intuition is that the impact of adopting the committee system should be greatest for those companies with the least pre-adoption foreign influence; companies with large foreign shareholders are the most likely to have been influenced by non-Japanese governance principles at an earlier point. The impact of adoption thus should be most visible for companies with the least prior foreign influence on their governance and business. Our results, however, are inconsistent with this hypothesis. For both sub-samples, abnormal 
returns on announcement are not statistically significant. ${ }^{75}$ Thus, we found no significant difference between the groups or between either group and the full sample.

Third, the absence of statistically significant abnormal returns for the entire sample may be the result of an endogeneity induced composition problem. We would expect significant positive or negative returns to adopting firms as a whole only if a "U.S." board structure is universally viewed as superior or inferior to a "Japanese" board structure. Otherwise, gains to firms whose production technology is complemented by a committee system may be offset by losses to firms for whom the new system in inconsistent with the firm's production technology. Because of this link between governance and production techniques, and because individual companies may make mistakes concerning the nature of that link to itself, results associated with particular companies may "wash out" in the aggregate

We attempted to address the endogeneity problem by running a separate event study for each publicly traded adopting firm (other than the Hitachi affiliates) for which data were available. Examination of the experience of individual firms with an eye to their particular characteristics (possible because of the small number of relevant observations) would be suggestive in evaluating the diversity of experience among firms: did some firms experience significant abnormal returns associated with announcement of adoptions, suggesting that our aggregate return was influenced by endogeneity, or did most companies share the aggregate experience, which would suggest that the absence of valuation effects, at least for early adopters, was not driven by the particular production characteristics of individual companies.

\footnotetext{
${ }^{75}$ The average abnormal return for firms in the first, more international sub-sample, were positive but insignificant. The average abnormal return for firms in the second, more domestic sub-sample, were negative but insignificant.
} 
Significant abnormal returns occurred at the announcement date for three firms: Ichiyoshi Securities, Toyama Chemical and Resona Holdings (all three firms were in our sub-sample of relatively "domestic" adopting firms). Table 5 shows the results of the firm level event study.

Table 5

\begin{tabular}{|c|c|c|}
\hline Firm & Market Adjusted Return (\%) & $\mathbf{z}$ \\
\hline Ichiyoshi Securities & -6.54 & -1.955 \\
\hline Toyama Chemical & -8.16 & -2.982 \\
\hline Resona Holdings & 8.32 & 2.639 \\
\hline
\end{tabular}

As Table 5 indicates, there was a statistically significant negative market reaction to the adoptions by Ichiyoshi (95 percent confidence level) and Toyama (99 percent confidence level). Ichiyoshi is a mid-sized brokerage firm affiliated with Nomura Securities, whose business is focused on the domestic market. Toyama is a mid-sized prescription drug manufacturer that has struggled in recent years. In neither case were we able to discern an endogeneity driven explanation for the results. Thus, we are unable to account for the negative market reactions to their announcements. The Resona Holdings announcement, in contrast, elicited a statistically significant (99 percent confidence level) positive reaction. Here we do have a conjecture about the source of the gains.

Recall that shortly prior to its adoption of the committee system, Resona Bank (the core firm of the holding company), was recapitalized with taxpayer funds. The decision to adopt the committee system was thus made by the Financial Services Agency, regulator of Japan's banking and securities industries. Public statements by the Minister 
of the FSA leading up to the adoption suggest that the motivation was a desire to improve corporate governance and transparency at a bank that had received an injection of public funds. ${ }^{76}$ It is thus possible that the market was reacting, not only or even principally to the 2002 reform, but to a perceived signal that the financial regulators were (finally) committed to turning around Resona and the troubled banking sector as a whole.

\section{Directors, Complementarities and Convergence}

In this final section, we evaluate - tentatively, to be sure, given the early stage of the reforms and the level of indeterminacy we have just noted — the implications and limitations of Japan's novel experiment with choice-based corporate governance reform.

We begin with a simple observation: Japan's recent corporate governance reform is a striking example of formal, but not functional convergence. ${ }^{77}$ Japan transplanted some visible components of a U.S.-style board committee structure, but not the complementary institutions that exponentially increase the functionality of the committee system in the host country. In the United States, the judicial system serves as a crucial complement to the committee structure. The Delaware courts are willing to grant deference to the decisions of directors in settings that pose significant risks of expropriation of minority shareholder wealth, if those decisions are made by an independent committee of the board in circumstances that replicate, as nearly as possible, arms' length negotiations. ${ }^{78}$ These cases, in turn, have created significant incentives for

\footnotetext{
${ }^{76}$ See Nihon keizai shimbun, (2003) (quoting Financial Services Agency Minister Heizo Takenaka as saying "In view of [the public injection of funds into the bank], it should be recognized that governance was inadequate. It is necessary to consider structuring the company to allow outside directors to appoint the representative directors and make similar decisions.").

${ }_{77}^{77}$ See Gilson, supra note 3 (Globalization of Corporate Governance).

${ }^{78}$ See, e.g., Weinberger v. UOP, Inc., 457 A.2d 701 (Del. S. Ct. 1983); see also Ronald J. Gilson \& Jeffrey Gordon, Controlling Controlling Shareholders, 152 U. Pa. L. Rev. 785 (2003).
} 
boards to utilize independent committees to structure and negotiate conflicting interest transactions. Recent cases such as the Oracle $^{79}$ decision highlight the role of the Delaware Chancery Court in policing directorial independence as a prerequisite to granting deference toward business decisions where potential conflicts of interest are present, and the expansive view of what independence entails. For the Delaware courts, independence is compromised not only by financial interest in the subject matter, but by personal and other relationships to the interested party. ${ }^{80}$

Japan lacks the body of judicial doctrine necessary to complement the committee structure in this way. Japanese courts are generally unaccustomed to applying flexible, ex post fiduciary standards in conflict of interest settings, relying instead on bright line procedural rules in the Commercial Code that are unlikely to be helpful in addressing board conflicts. ${ }^{81}$ Indeed, the development of such doctrine may be foreclosed by the 2002 reform, absent uncharacteristically bold judicial activism on the part of the Japanese courts. Given that the definition of outside director in the Code does not contemplate anything like complete independence, it is difficult to imagine Japanese courts finding that a committee decision is not entitled to deference because the outside members of the committee were not truly independent. Rather, the opposite result seems more likely: the fact that a committee comprised substantially of "outside" directors endorsed a decision will lend extra credibility to the action in the eyes of the courts. Thus, without the complement of exacting ex post judicial review, the new committee system--in tandem

\footnotetext{
${ }^{79}$ In re Oracle Derivative Litig., 824 A.2d 917 (Del. Ch. 2003) (finding special litigation committee members affiliated with Stanford University lacked independence, where several defendant directors had personal or professional ties to Stanford).

${ }^{80}$ See Oracle, supra note 80 at $937-940$.

${ }^{81}$ See Hideki Kanda and Curtis J. Milhaupt, Re-examining Legal Transplants: The Directors' Fiduciary Duty in Japanese Corporate Law, 51 Am. J. Comp. L. 887 (2003).
} 
with the Code's expansive definition of outside director--could actually become a potent new governance technology for stakeholder tunneling and managerial entrenchment. ${ }^{82}$

This analysis, together with the first round adoption data we presented above, suggests that adoption of the committee system performs at best a very weak signaling and bonding function, consistent with the absence of any systematic price movement on announcement. It could well be that other institutional constraints, working in tandem with the committee structure, will emerge to form a complementary new governance structure. ${ }^{83}$ But those complementarities are not apparent at this stage, and even if they emerge in the future, they are likely to look quite different than those currently at work in the United States. In a sense, this is unsurprising, because as our discussion of the political dynamics leading to the 2002 reform indicates, adoption of the committee enabling approach was the result of only a selective and skeptical embrace of the U.S. corporate governance model.

Ultimately, perhaps what is most interesting about Japan's new approach to corporate governance reform is the characteristically distinctive way it underscores what we already know: The transmission of ideas from one system to another is highly

\footnotetext{
${ }^{82}$ This is not a farfetched concern. Keidanren, which represents the interests of major Japanese corporations, recently proposed that the Commercial Code be amended to permit the establishment of special litigation committees to respond to shareholder derivative suits. The proposal approvingly cites the U.S. ALI Principles of Corporate Governance and implicitly suggests that, as in the United States, Japanese courts should "respect" a decision of the special litigation committee not to pursue the litigation. Nippon Keidanren, Proposal for Revision of the Corporations Law, Oct. 16, 2003. But the proposal lacks any acknowledgement of the institutional differences that separate the U.S. and Japan, and at least to the extent a comparison with U.S. law is implicit, it misrepresents the degree of deference that the Delaware courts grant to special litigation committee decisions not to pursue a derivative suit. See Zapata v. Maldanado, 430 A.2d 779 (Del. S. Ct. 1981).

${ }^{83}$ It is also possible that the most significant consequence of the introduction of the committee system option will be its influence on firms that retain the statutory auditor system. There is preliminary evidence, for example, that the introduction of the committee system has encouraged non-adopting firms to shorten the terms of their directors to one year (which is required for committee system firms). See 233 Shiroban shoji homu 32 (2003) (reporting that during the 2003 summer shareholder meeting season, 210 firms-1.6 times more than in the previous year-shortened the term of their directors to one year).
} 
complex, and thus despite outward appearances of convergence of purpose in corporate governance reform around the world, the trajectory and end point of reform in any given system will be shaped by intensely local forces. ${ }^{84}$ Although the end point of Japan's experiment with an enabling approach to corporate governance is far from clear, little in the path of reform to date suggests that "choice" implies convergence, either with the U.S. model-- or even on a single new J-Form corporate governance.

\section{Conclusion}

Corporate governance reform in Japan has taken a distinctive turn. Rather than adopting mandatory reform of its corporate law, Japan chose an enabling strategy, offering firms the option of switching from "Japanese" to "U.S." board structure. In this paper, we have examined the first year's data on this interesting natural experiment in the attractiveness of U.S.-style corporate governance structures.

The results thus far - although admittedly very preliminary — suggest that several, non-exclusive strategies may have driven the choices of firms opting into the board/committee system. These range from (possibly ineffectual) signaling of adherence to "good" governance practices, and selection of endogenously determined structures optimal to a specific firm's production technology and competitive market, to tightening parent company control over affiliates within a group. The absence of a single, clear

\footnotetext{
${ }^{84}$ See, e.g., Gerald F. Davis and Doug McAdam, Corporations, Classes, and Social Movements After Managerialism, 22 Res. Org. Behav. 195 (2000) (viewing changes in economic activity as episodic forms of collective action stimulated by destabilizing changes in the political status quo); Gerald F. David and Tracey A. Thompson, A Social Movement Perspective on Corporate Control, 39 Admin, Sci. Q 141 (1994) (stressing that governance regimes evolve within domestic social and political structures). See also Crristina L. Ahmadjian \& Jaeyong Song, Corporate Governance Reform in Japan and South Korea: Two Paths of Globalization, unpublished working paper (2004) (globalization resulted in different paths of change in Japan and Korea due to differences in resource dependencies on global capital, ideology, and political dynamics).
} 
strategy pursued by adopting firms - and the overall absence of significant stock market reaction to adoption of the committee system--reflects the ambiguous underlying dynamics that led to the enabling approach over the imposition of mandatory board reforms. Simply put, "choice" was the product of compromise, not overwhelming consensus on (or empirical support for) the advisability of moving toward U.S.-style corporate governance. Consistent with this ambivalence among affected constituencies, board composition of adopting firms appears to be bifurcated between group-oriented firms, which lack truly independent directors, and non-group firms, which appear to have appointed more independent directors to their boards.

The 2002 reform is an interesting illustration of formal, but not functional, convergence. Perhaps Japanese firms will utilize the new board/committee option to create governance mechanisms that function quite similar to those of U.S. firms. But that result is not required by the legal reforms, particularly in the absence of ex post judicial review of directorial independence, an important complement to independent board committees in the United States. Only further experience with the reforms occurring with the passage of time can further inform our initial analysis of the data. But even these very early responses to "choice" help illuminate the path of future development in Japanese corporate governance. 
Table 2: Name and Industry Classification of Adopting Firms

\begin{tabular}{|c|c|c|c|}
\hline $\begin{array}{l}\text { Corporate Name } \\
\text { 1. Sumida Corporation } \\
\text { 2. Aeon } \\
\text { 3. Parco } \\
\text { 4. Seiyu } \\
\text { 5. Toyama Chemical } \\
\text { 6. Nissei } \\
\text { 7. Konica Minolta } \\
\text { 8. Hitachi } \\
\text { 9. Hitachi Plant E\&C } \\
\text { 10. Hitachi Chemical } \\
\text { 11. Hitachi Metals } \\
\text { 12. Hitachi Cable } \\
\text { 13. Hitachi Powdered Metals } \\
\text { 14. Hitachi Construction Machin. } \\
\text { 15. Hitachi Kiden Kogyo } \\
\text { 16. Nippon Servo } \\
\text { 17. Hitachi Kokusai Electric } \\
\text { 18. Hitachi Maxell } \\
\text { 19. Hitachi Medical } \\
\text { 20. Shin Kobe Electronics } \\
\text { 21. Hitachi Hi-Technologies } \\
\text { 22. Hitachi Capital } \\
\text { 23. Hitachi Transport System } \\
\text { 24. Hitachi Mobile } \\
\text { 25. Hitachi Software Engineering } \\
\text { 26. Hitachi Information Systems } \\
\text { 27. Hitachi AIC } \\
\text { 28. Hitachi House Technology } \\
\text { 29. Hitachi Kasei Shoji } \\
\text { 30. Toshiba } \\
\text { 31. Mitsubishi Electric } \\
\text { 32. Sony } \\
\text { 33. Shizuki Electric } \\
\text { 34. Nojima } \\
\text { 35. HOYA }\end{array}$ & $\begin{array}{l}\text { Ind. Classification } \\
\text { Electronics } \\
\text { Retail } \\
\text { Retail } \\
\text { Retail } \\
\text { Pharma } \\
\text { Machinery } \\
\text { Chemicals } \\
\text { Electronics } \\
\text { Construction } \\
\text { Chemicals } \\
\text { Iron \& Steel } \\
\text { Nonferrous Metal } \\
\text { Metal Prod. } \\
\text { Machinery } \\
\text { Machinery } \\
\text { Electronics } \\
\text { Electronics } \\
\text { Electronics } \\
\text { Medical } \\
\text { Electronics } \\
\text { Wholesale } \\
\text { Other Financing } \\
\text { Land Transp. } \\
\text { Info \& Comm. } \\
\text { Info \& Comm. } \\
\text { Info \& Comm. } \\
\text { Electronics } \\
\text { Construction } \\
\text { Wholesale } \\
\text { Electronics } \\
\text { Electronics } \\
\text { Electronics } \\
\text { Electronics } \\
\text { Retail } \\
\text { Precision Instruments }\end{array}$ & $\begin{array}{l}\text { Corporate Name } \\
\text { 36. Shaddy } \\
\text { 37. Resona Holdings } \\
\text { 38. Resona Bank } \\
\text { 39. Orix } \\
\text { 40. Nomura Holdings } \\
\text { 41. Nomura Securities } \\
\text { 42. Nomura Asset Management } \\
\text { 43. Nomura Trust Bank } \\
\text { 44. Nomura Babcock \& Brown } \\
\text { 45. Nomura Investment } \\
\text { 46. Nomura Investor Relations } \\
\text { 47. Nomura Principal Finance } \\
\text { 48. Nomura Annuity Support Serv. } \\
\text { 49.Nomura Fund Research \& Tech. } \\
\text { 50. Nomura Research \& Advisory } \\
\text { 51. Nomura Business Service } \\
\text { 52. Nomura Satellite } \\
\text { 53. Nomura Asset Properties } \\
\text { 54. Ichiyoshi Securities } \\
\text { 55. Vodafone Holdings } \\
\text { 56. Vodafone } \\
\text { 57. Japan Telecom } \\
\text { 58. Gakkyusha } \\
\text { 59. Tokyo Star Bank } \\
\text { 60. Manulife } \\
\text { 61. Niles } \\
\text { 62. Columbia Music Entertainment } \\
\text { 63. D\&M Holdings } \\
\text { 64. Japan Herald Film } \\
\text { 65. Mega Chips System Solutions } \\
\text { 66.People } \\
\text { 67. Niws } \\
\text { 68. Rokko \& Associates } \\
\text { 69. JOW Corporation } \\
\text { 70. Silex Technologies } \\
\text { 71. Mycal Kyushu } \\
\text { a }\end{array}$ & $\begin{array}{l}\text { Ind. Classification } \\
\text { Wholesale } \\
\text { Banking } \\
\text { Banking } \\
\text { Other Financing } \\
\text { Securities } \\
\text { Securities } \\
\text { Other Financing } \\
\text { Banking } \\
\text { Other Financing } \\
\text { Other Financing } \\
\text { Info \& Comm. } \\
\text { Other Financing } \\
\text { Services } \\
\text { Other Financing } \\
\text { Info \& Comm. } \\
\text { Services } \\
\text { Info \& Comm. } \\
\text { Other Financing } \\
\text { Securities } \\
\text { Info \& Comm. } \\
\text { Info \& Comm. } \\
\text { Info \& Comm. } \\
\text { Services } \\
\text { Banking } \\
\text { Insurance } \\
\text { Machinery } \\
\text { Info \& Comm. } \\
\text { Electronics } \\
\text { Info \& Comm. } \\
\text { Info \& Comm. } \\
\text { Other products } \\
\text { Wholesale } \\
\text { Machinery } \\
\text { Construction } \\
\text { Electronics } \\
\text { Retail trade }\end{array}$ \\
\hline
\end{tabular}


Table 3: Foreign Ownership and Cross-Listing of Adopting Firms

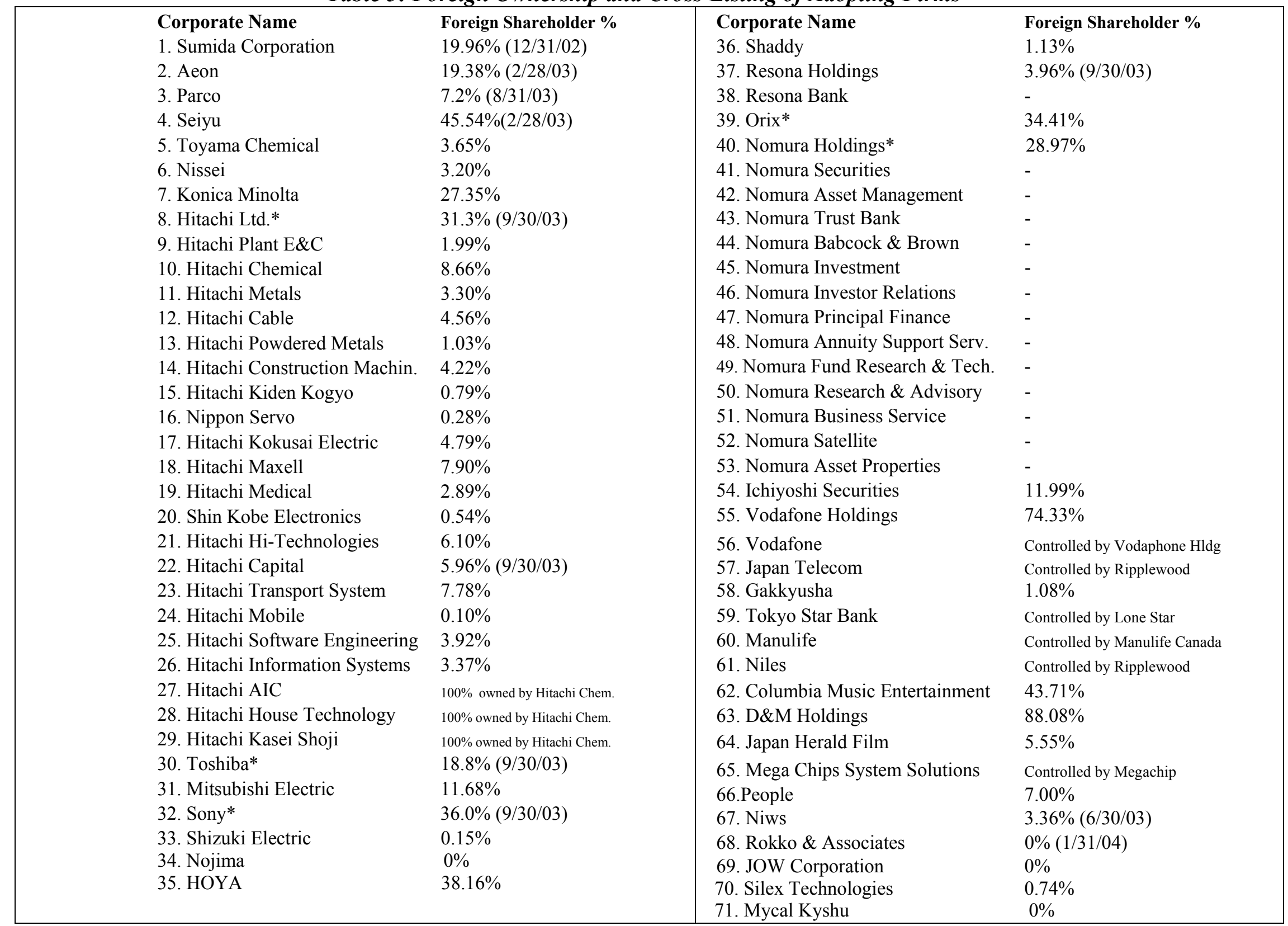

Notes: Unless otherwise noted, as of 3/30/2003. * = ADRs listed on NYSE. 


\begin{tabular}{|c|c|c|c|c|c|c|c|c|c|c|c|c|c|c|c|c|c|}
\hline & \multirow[t]{2}{*}{ Corporate Name } & \multicolumn{3}{|c|}{ Number of Directors } & \multicolumn{3}{|c|}{ Nomination Committee } & \multicolumn{3}{|c|}{ Audit Committee } & \multicolumn{3}{|c|}{ Compensation Committee } & \multicolumn{4}{|c|}{ Number of Officers } \\
\hline & & & $\begin{array}{l}\text { Out. } \\
\text { Dir. }\end{array}$ & $\%$ & & $\begin{array}{l}\text { Out. } \\
\text { Dir. }\end{array}$ & & & $\begin{array}{l}\text { Out. } \\
\text { Dir. }\end{array}$ & $\%$ & & $\begin{array}{l}\text { Out. } \\
\text { Dir. }\end{array}$ & & & $\begin{array}{l}\text { \# of } \\
\text { Rep.Off. }\end{array}$ & $\begin{array}{l}\text { \# of Exec. } \\
\text { Dir. }\end{array}$ & $\%$ \\
\hline 1 & Sumida Corporation & 11 & 4 & $36 \%$ & 5 & 3 & $60 \%$ & 5 & 3 & $60 \%$ & 5 & 3 & $60 \%$ & 3 & 3 & 2 & $67 \%$ \\
\hline 2 & Aeon & 8 & 4 & $50 \%$ & 3 & 2 & $67 \%$ & 3 & 3 & $100 \%$ & 3 & 2 & $67 \%$ & 20 & 2 & 3 & $15 \%$ \\
\hline 3 & Parco & 9 & 4 & $44 \%$ & 4 & 3 & $75 \%$ & 4 & 4 & $100 \%$ & 4 & 3 & $75 \%$ & 11 & 2 & 5 & $45 \%$ \\
\hline 4 & Seiyu & 12 & 7 & $58 \%$ & 5 & 3 & $60 \%$ & 3 & 3 & $100 \%$ & 5 & 3 & $60 \%$ & 11 & 2 & 5 & $45 \%$ \\
\hline 5 & Toyama Chemical & 9 & 4 & $44 \%$ & 4 & 3 & $75 \%$ & 4 & 3 & $75 \%$ & 3 & 2 & $67 \%$ & 13 & 1 & 4 & $31 \%$ \\
\hline 6 & Nissei & 6 & 3 & $50 \%$ & 5 & 3 & $60 \%$ & 3 & 2 & $67 \%$ & 3 & 2 & $67 \%$ & 8 & 1 & 2 & $25 \%$ \\
\hline 7 & Konica Minolta & 12 & 4 & $33 \%$ & 5 & 3 & $60 \%$ & 5 & 3 & $60 \%$ & 5 & 3 & $60 \%$ & 26 & 2 & 5 & $19 \%$ \\
\hline 8 & Hitachi & 13 & 4 & $31 \%$ & 5 & 3 & $60 \%$ & 5 & 3 & $60 \%$ & 5 & 3 & $60 \%$ & 29 & 5 & 3 & $10 \%$ \\
\hline 9 & Hitachi Plant E\&C & 8 & 3 & $38 \%$ & 3 & 2 & $67 \%$ & 4 & 3 & $75 \%$ & 3 & 2 & $67 \%$ & 22 & 2 & 4 & $18 \%$ \\
\hline 10 & Hitachi Chemical & 8 & 3 & $38 \%$ & 5 & 3 & $60 \%$ & 3 & 2 & $67 \%$ & 3 & 2 & $67 \%$ & 11 & 3 & 3 & $27 \%$ \\
\hline 11 & Hitachi Metals & 6 & 3 & $50 \%$ & 3 & 2 & $67 \%$ & 3 & 2 & $67 \%$ & 3 & 2 & $67 \%$ & 4 & 2 & 2 & $50 \%$ \\
\hline 12 & Hitachi Cable & 8 & 3 & $38 \%$ & 3 & 2 & $67 \%$ & 3 & 2 & $67 \%$ & 3 & 2 & $67 \%$ & 14 & 2 & 4 & $29 \%$ \\
\hline 13 & Hitachi Powdered Metals & 8 & 3 & $50 \%$ & 3 & 2 & $67 \%$ & 3 & 2 & $67 \%$ & 3 & 2 & $67 \%$ & 10 & 1 & 2 & $20 \%$ \\
\hline 14 & Hitachi Construction Machinery & 8 & 3 & $38 \%$ & 5 & 3 & $60 \%$ & 4 & 3 & $75 \%$ & 3 & 2 & $67 \%$ & 18 & 3 & 4 & $22 \%$ \\
\hline 15 & Hitachi Kiden Kogyo & 7 & 2 & $29 \%$ & 3 & 2 & $67 \%$ & 3 & 2 & $67 \%$ & 3 & 2 & $67 \%$ & 9 & 1 & 3 & $33 \%$ \\
\hline 16 & Nippon Servo & 7 & 2 & $29 \%$ & 3 & 2 & $67 \%$ & 3 & 2 & $67 \%$ & 3 & 2 & $67 \%$ & 9 & 1 & 3 & $33 \%$ \\
\hline 17 & Hitachi Kokusai Electric & 5 & 3 & $60 \%$ & 3 & 2 & $67 \%$ & 3 & 2 & $67 \%$ & 3 & 2 & $67 \%$ & 10 & 1 & 1 & $10 \%$ \\
\hline 18 & Hitachi Maxell & 8 & 3 & $38 \%$ & 5 & 3 & $60 \%$ & 4 & 3 & $75 \%$ & 3 & 2 & $67 \%$ & 14 & 2 & 4 & $29 \%$ \\
\hline 19 & Hitachi Medical & 8 & 3 & $38 \%$ & 3 & 2 & $67 \%$ & 3 & 2 & $67 \%$ & 3 & 2 & $67 \%$ & 13 & 2 & 3 & $23 \%$ \\
\hline 20 & Shin Kobe Electronics & 7 & 3 & $43 \%$ & 3 & 2 & $67 \%$ & 3 & 2 & $67 \%$ & 3 & 2 & $67 \%$ & 9 & 1 & 3 & $33 \%$ \\
\hline 21 & Hitachi Hi-Technologies & 7 & 2 & $29 \%$ & 3 & 2 & $67 \%$ & 3 & 2 & $67 \%$ & 3 & 2 & $67 \%$ & 18 & 3 & 3 & $17 \%$ \\
\hline 22 & Hitachi Capital & 6 & 3 & $50 \%$ & 3 & 2 & $67 \%$ & 3 & 2 & $67 \%$ & 3 & 2 & $67 \%$ & 8 & 1 & 1 & $13 \%$ \\
\hline 23 & Hitachi Transport System & 6 & 2 & $33 \%$ & 3 & 2 & $67 \%$ & 3 & 2 & $67 \%$ & 3 & 2 & $67 \%$ & 15 & 2 & 2 & $13 \%$ \\
\hline 24 & Hitachi Mobile & 7 & 2 & $29 \%$ & 3 & 2 & $67 \%$ & 3 & 2 & $67 \%$ & 3 & 2 & $67 \%$ & 9 & 1 & 3 & $33 \%$ \\
\hline 25 & Hitachi Software Engineering & 6 & 2 & $33 \%$ & 3 & 2 & $67 \%$ & 3 & 2 & $67 \%$ & 3 & 2 & $67 \%$ & 16 & 2 & 3 & $19 \%$ \\
\hline 26 & Hitachi Information Systems & 8 & 3 & $38 \%$ & 3 & 2 & $67 \%$ & 3 & 2 & $67 \%$ & 3 & 2 & $67 \%$ & 17 & 2 & 4 & $24 \%$ \\
\hline 27 & Hitachi AIC & 6 & 2 & $33 \%$ & 3 & 2 & $67 \%$ & 3 & 2 & $67 \%$ & 3 & 2 & $67 \%$ & 8 & 1 & 3 & $38 \%$ \\
\hline 28 & Hitachi House Technologies & 6 & 3 & $50 \%$ & 3 & 2 & $67 \%$ & 3 & 3 & $100 \%$ & 3 & 2 & $67 \%$ & 6 & 1 & 2 & $33 \%$ \\
\hline 29 & Hitachi Kasei Shoji & 8 & 3 & $38 \%$ & 3 & 2 & $67 \%$ & 3 & 2 & $67 \%$ & 3 & 2 & $67 \%$ & 6 & 1 & 3 & $50 \%$ \\
\hline 30 & Toshiba & 16 & 4 & $25 \%$ & 3 & 2 & $67 \%$ & 5 & 3 & $60 \%$ & 5 & 3 & $60 \%$ & 35 & 4 & 9 & $29 \%$ \\
\hline 31 & Mitsubishi Electric & 12 & 5 & $42 \%$ & 5 & 3 & $60 \%$ & 5 & 3 & $60 \%$ & 5 & 3 & $60 \%$ & 19 & 3 & 3 & $16 \%$ \\
\hline 32 & Sony & 17 & 8 & $47 \%$ & 5 & 3 & $60 \%$ & 3 & 2 & $67 \%$ & 3 & 2 & $67 \%$ & 12 & 3 & 8 & $67 \%$ \\
\hline 33 & Shizuki Electric & 7 & 3 & $43 \%$ & 5 & 3 & $60 \%$ & 3 & 2 & $67 \%$ & 3 & 2 & $67 \%$ & 9 & 1 & 3 & $33 \%$ \\
\hline 34 & Nojima & 10 & 6 & $60 \%$ & 5 & 3 & $60 \%$ & 4 & 3 & $75 \%$ & 5 & 3 & $60 \%$ & 7 & 1 & 3 & $43 \%$ \\
\hline 35 & HOYA & 8 & 5 & $63 \%$ & 5 & 5 & $100 \%$ & 5 & 5 & $100 \%$ & 5 & 5 & $100 \%$ & 3 & 1 & 3 & $100 \%$ \\
\hline 36 & Shaddy & 5 & 2 & $40 \%$ & 3 & 2 & $67 \%$ & 3 & 2 & $67 \%$ & 3 & 2 & $67 \%$ & 12 & 1 & 2 & $17 \%$ \\
\hline 37 & Resona Holdings & 10 & 6 & $60 \%$ & 3 & 2 & $67 \%$ & 4 & 3 & $75 \%$ & 3 & 2 & $67 \%$ & 8 & 3 & 3 & $38 \%$ \\
\hline 38 & Resona Bank & 11 & 6 & $55 \%$ & 3 & 2 & $67 \%$ & 4 & 3 & $75 \%$ & 3 & 2 & $67 \%$ & 24 & 3 & 3 & $13 \%$ \\
\hline 39 & Orix & 12 & 4 & $33 \%$ & 5 & 3 & $60 \%$ & 3 & 2 & $67 \%$ & 5 & 3 & $60 \%$ & 22 & 2 & 7 & $32 \%$ \\
\hline 40 & Nomura Holdings & 11 & 4 & $36 \%$ & 3 & 2 & $67 \%$ & 3 & 2 & $67 \%$ & 3 & 2 & $67 \%$ & 27 & 3 & 4 & $15 \%$ \\
\hline 41 & Nomura Securities & 10 & 6 & $60 \%$ & 3 & 2 & $67 \%$ & 3 & 3 & $100 \%$ & 3 & 2 & $67 \%$ & 32 & 6 & 3 & $9 \%$ \\
\hline
\end{tabular}


42 Nomura Asset Management

43 Nomura Trust Bank

44 Nomura Babcock \& Brown

45 Nomura Investment

46 Nomura Investor Relations

47 Nomura Principal Finance

48 Nomura Annuity Support \& Services

49 Nomura Fund Research \& Tech.

50 Nomura Research and Advisory

51 Nomura Business Service

52 Nomura Satellite

53 Nomura Asset Properties

54 Ichiyoshi Securities

55 Vodafone Holdings

56 Vodafone

57 Japan Telecom

58 Gakkyusha

59 Tokyo Star Bank

60 Manulife

61 Niles

62 Columbia Music Entertainment

63 D\&M Holdings

64 Japan Herald Film

65 Mega Chips System Solutions

66 People

67 Niws

68 Rokko \& Associates

69 JOW Corporation

70 Silex Technology, Inc.

71 Mycal Kyushu Corporation

\begin{tabular}{|r|r|r|}
7 & 5 & $71 \%$ \\
6 & 4 & $67 \%$ \\
6 & 5 & $83 \%$ \\
6 & 5 & $83 \%$ \\
6 & 5 & $83 \%$ \\
6 & 5 & $83 \%$ \\
6 & 4 & $67 \%$ \\
6 & 5 & $83 \%$ \\
6 & 5 & $83 \%$ \\
6 & 5 & $83 \%$ \\
6 & 5 & $83 \%$ \\
6 & 4 & $67 \%$ \\
8 & 2 & $25 \%$ \\
9 & 6 & $67 \%$ \\
9 & 6 & $67 \%$ \\
9 & 6 & $67 \%$ \\
6 & 3 & $50 \%$ \\
11 & 6 & $55 \%$ \\
9 & 7 & $78 \%$ \\
7 & 4 & $57 \%$ \\
7 & 4 & $57 \%$ \\
11 & 5 & $45 \%$ \\
8 & 2 & $25 \%$ \\
7 & 2 & $25 \%$ \\
5 & 3 & $60 \%$ \\
14 & 4 & $29 \%$ \\
10 & 2 & $20 \%$ \\
9 & 5 & $56 \%$ \\
6 & 3 & $50 \%$ \\
6 & 6 & $100 \%$ \\
\hline
\end{tabular}


